\title{
Influence of Reduced Salinity on the Histochemical Fiber Type Composition of the Claw Closer Muscle of Two Estuarine Crab Species, Cyrtograpsus angulatus and Neohelice granulata (Decapoda: Varunidae)
}

\author{
Influencia de la Salinidad Reducida sobre la Composición Histoquímica de Tipos de Fibras \\ del Músculo de Cierre de las Quelas de Dos Especies de Cangrejos Estuariales, \\ Cyrtograpsus angulatus y Neohelice granulata (Decapoda: Varunidae)
}

María Victoria Longo ${ }^{1}$ \& Alcira Ofelia Díaz ${ }^{1}$

LONGO, M. V. \& DÍAZ, A. O. Influence of reduced salinity on the histochemical fiber type composition of the claw closer muscle of two estuarine crab species, Cyrtograpsus angulatus and Neohelice granulata (Decapoda: Varunidae). Int. J. Morphol., 35(2):533-540, 2017.

SUMMARY: The estuarine crustaceans are exposed to frequent and abrupt environmental salinity changes that involve adjustments at different levels in muscle tissue. The histochemical composition of fiber types of the claw closer muscle of Cyrtograpsus angulatus and Neohelice granulata (Dana, 1851) under hyper regulatory conditions was analyzed. Cryosections of the muscle were treated with myosin-adenosine triphosphatase (m-ATPase), succinic dehydrogenase (SDH), periodic acid Schiff (PAS) and Sudan Black B. The mean diameters, the relative area and the proportion of each muscle fiber type were calculated. Types I and IV would belong to 'extreme' groups, whereas types II and III would be considered 'intermediate'. Type I fibers were large and exhibited a weak reaction to all techniques; type IV fibers were small and reacted strongly to histochemical tests. Types II and III prevailed in C. angulatus whereas type II predominated in $N$. granulata. Type IV fibers were absent in $C$. angulatus and scarce in $N$. granulata. The claw closer muscle of $N$. granulata and $C$. angulatus exhibited differential responses under reduced salinity at a histochemical level. Therefore, the existence of different adjustment mechanisms facing salinity stress is suggested.

KEY WORDS: Euryhaline crabs; Histochemistry; Hyper regulation; Muscle fibers; Salinity stress.

\section{INTRODUCTION}

Organisms inhabiting estuaries are exposed to frequent and abrupt environmental salinity changes. These fluctuations require adjustments at biochemical, physiological, morphological and behavioral levels in order to control the water and ion movements between individuals and the environment (Kirschner, 2004; McNamara \& Faria, 2012; Romano \& Zeng, 2012).

In general, the estuarine crustaceans are osmoregulators at reduced salinity (hyper-regulators) and osmoconformers at high salinity (Freire et al., 2008; McNamara \& Faria). At low salinities, they hyper regulate actively by absorbing through their gills $\mathrm{Na}+$ and $\mathrm{Cl}$ - from the environment (Kirschner). The muscle and the hepatopancreas take part in adjustment mechanisms subsidiary to osmo-ionoregulation (Li et al., 2008; Martins et al., 2011; Michiels et al., 2013; Pinoni et al., 2013; Longo \& Díaz, 2015). For instance, the muscle has been involved in lipid mobilization under hyposmotic stress (LuvizottoSantos et al., 2003) and in the differential response of diverse enzymes in osmoregulatory and osmoconformatory conditions (Pinoni \& López Mañanes, 2008; Pinoni \& López Mañanes, 2009).

In crustaceans, all types of muscle fibers are transversally striated and exhibit a great ultrastructural, histochemical, biochemical and physiological diversity. Two functional extreme types are acknowledged: rapid and slow

\footnotetext{
${ }^{1}$ Instituto de Investigaciones Marinas y Costeras (IIMyC), FCEyN, Universidad Nacional de Mar del Plata, CONICET, Funes $32503^{\circ}$ piso, (7600) Mar del Plata, Buenos Aires, Argentina.

This research was supported by grants from the University of Mar del Plata, Argentina (EXA 491/10, 15/E439 and EXA 578/12, 15/E526).
} 
fibers, together with a wide spectrum of intermediate types (Neil et al., 1993; Perry et al., 2009; Longo \& Díaz, 2013a,b).

The most widely used histochemical techniques for the characterization of muscle fiber types measure the enzyme myosin-adenosine triphosphatase (m-ATPase) and the fiber oxidative capacity (Neil et al.; Gruhn \& Rathmayer, 2002). Preincubation at different $\mathrm{pH}$ 's and temperature changes allow revealing a wider variety of fiber types (Neil et al.; Gruhn \& Rathmayer; Longo et al., 2011).

Cyrtograpsus angulatus and Neohelice granulata (Decapoda, Varunidae) are euryhaline crabs, considered as "key species" in temperate-warm Southwest Atlantic coastal mudflat ecosystems (Spivak, 1997). N. granulata is a semiterrestrial and burrowing crab inhabiting tidal flats and Spartina densiflora mudflats of the outer or estuarial region of the Mar Chiquita coastal lagoon (province of Buenos Aires). As a detritus feeder, $N$. granulata is primordial in the production and integrity of these estuarine environments (Alberti et al., 2008). C. angulatus has more aquatic habits. Adults live in the intertidal and subtidal zones everywhere throughout Mar Chiquita, including fresh, brackish and marine water environments. It is an omnivorous species: in Mar Chiquita it feeds on annelids and is also a scavenger (Olivier et al., 1972). C. angulatus and N. granulata behave as hyper/hyporegulators upon acclimation to 6-10 practical salinity units (psu) and 45-60 psu, respectively, and they osmoconform at $35 \mathrm{psu}$. These osmoregulatory responses, reached after 10 days' acclimation, are maintained stable for longer periods (up to three months) at all salinities tested: 6,10,35,45 and 60 psu (Michiels et al.; Pinoni et al.).

In a previous study Longo \& Díaz (2013a) analyzed the histochemical composition of the claw closer muscle fibers of $C$. angulatus and $N$. granulata in the osmoconformation condition ( $35 \mathrm{psu}=$ control condition). Among species a variation in the fiber type proportions was observed, which would be related to different habitats and feeding ways (Longo \& Díaz, 2013a).

Previous adjustment works at a biochemical level demonstrated that under salinity changes $C$. angulatus and $N$. granulata exhibit complex osmoregulatory mechanisms that involve the key enzymes activity in the claw muscle (Pinoni \& López Mañanes, 2008; Pinoni \& López Mañanes, 2009). The lipids and glycogen contents of $N$. granulata muscles at different salinities were biochemically analyzed (Nery \& Santos, 1993; Luvizotto-Santos et al.; Pinoni et al.).

However, no studies have been reported on the histochemical characterization of the claw closer muscle subjected to hyper regulation for either crab species.
The histochemical analysis of the aforementioned muscle at reduced salinity will be of great contribution to the knowledge of complex adjustment mechanisms under salinity stress in $C$. angulatus and $N$. granulata.

Therefore, the aim of this work is to characterize the m-ATPase and SDH activities, as well as the $C$. angulatus and $N$. granulata claw closer muscle reserve in reduced salinity conditions (hyper regulation).

\section{MATERIAL AND METHOD}

Animals. Adult male crabs of $C$. angulatus $(\mathrm{n}=6)$ and $N$. granulata $(\mathrm{n}=6)$ were collected on mudflats from the Mar Chiquita lagoon ( $\left.37^{\circ} 32^{\prime} \mathrm{S}, 57^{\circ} 26^{\prime} \mathrm{W}\right)$, Province of Buenos Aires (Argentina) during low tide. We selected crabs with similar size claws (homochelae). At time of collection, the values of salinity in water ranged from 10 to $40 \mathrm{psu}$. Animals were transported to the laboratory in containers filled with water from the collection site. Then, they were acclimated in low salinity aquaria (10 psu) for 20 days prior to use. Diluted seawater was obtained by dilution of natural seawater with distilled water (Pinoni et al.). Continuous aeration and controlled conditions of temperature $22 \pm 2{ }^{\circ} \mathrm{C}$ and photoperiod 12:12 (L/D) were applied. Crabs were fed with commercial food (Cichlind T.E.N.; Wardley, Secaucus, NJ, USA) three times a week (Michiels et al.). The moult stage was determined through observation of setae from the maxilla (Moriyasu \& Mallet, 1986); intermoult individuals were selected. Before processing, the specimens were cold anesthetized and their claws removed. All procedures involving live animals were approved by the National University of Mar del Plata (EXA 491/10, 15/E439 and EXA 578/12, 15/E526).

Histochemistry. The claw closer muscles were fixed in liquid nitrogen $\left(-170{ }^{\circ} \mathrm{C}\right)$ into the cold room $\left(4{ }^{\circ} \mathrm{C}\right)$. Cryosections (10-15 $\mu \mathrm{m}$ thick) of the central region of the muscle were treated with histochemical techniques to identify different fiber types, as detailed in Table I.

Myosin-adenosine triphosphatase: acid and alkaline preincubation ( $\mathrm{pH} 4.6$ and 10.05 , respectively) and subsequent incubation at room temperature were carried out. The samples were incubated for $30 \mathrm{~min}$. A control procedure with sodium glycerophosphate in place of ATP was carried out.

Succinic Dehydrogenase: sections were incubated on moist filter paper, in a Petri dish, for $1-2 \mathrm{~h}$ at $40{ }^{\circ} \mathrm{C}$. Controls included incubations without sodium succinate substrate. 
LONGO, M. V. \& DÍAZ, A. O. Influence of reduced salinity on the histochemical fiber type composition of the claw closer muscle of two estuarine crab species, Cyrtograpsus angulatus and Neohelice granulata (Decapoda: Varunidae). Int. J. Morphol., 35(2):533-540, 2017.

Table I. Histochemical techniques for identifying fiber types in the claw closer muscles of Neohelice granulata and Cyrtograpsus angulatus.

\begin{tabular}{lll}
\hline \multicolumn{1}{c}{ Techniques } & \multicolumn{1}{c}{ Interpretation of staining reactions } & \multicolumn{1}{c}{ References } \\
\hline m-ATPase no preincubation & Different myosin isoforms & Günzel et al. (1993) \\
m-ATPase pre-incubation at pH 10.05 & Myosin isoform resistant to alkali & Maier et al. (1984) Günzel et al. \\
m-ATPase pre-incubation at pH 4.6 & Myosin isoform resistant to acid & Maier et al. Günzel et al. \\
SDH & Fibers with aerobic metabolism & Neil et al. (1993) \\
PAS & GPs with oxidizable vicinal diols andor glycogen & Mc Manus (1948) \\
Sudan Black B & Neutral and bound lipids & Johnson (1980)
\end{tabular}

References: m-ATPase, myosin-adenosine triphosphatase; PAS, periodic acid Schiff; SDH, succinic dehydrogenase.

Periodic Acid Schiff: the samples were processed with periodic acid, washed in running tap water and then, they were stained with Schiff reagent for $2-5 \mathrm{~min}$. As a control, the procedure was carried out after treatment of the sections with alpha-amylase for $45 \mathrm{~min}$.

Sudan Black B: sections were processed with a potassium dichromate solution for $75 \mathrm{~min}$. They were washed in tap water, brought to $70 \%$ alcohol and stained with Sudan black $\mathrm{B}$ for $16 \mathrm{~h}$. As a control, the procedure was carried out after acetone extraction.

The results were evaluated in a semiquantitative way: absence (0) and presence (from 1 to 4 ) of reactivity.

Morphometry. Photomicrographs of sections stained for mATPase were used to count the total number of fiber types in the entire muscle cross section. Every fiber was counted and allocated to one of the four fiber type categories. The relative proportion $(\%)$ of each muscle fiber type was calculated and the fiber diameters were measured according to Longo \& Díaz (2013a). These values were used to calculate the percentage of relative area for types I, II, III and IV fibers (Longo \& Díaz, 2013a).
Statistical analysis. Comparisons of fiber type proportions between the two species were made by using the chi square test. The effects of the fiber type and of the species on fiber diameters were analyzed by using the Kruskall-Wallis oneway analysis of variance test. Comparisons between pair of samples were carried out by a Dunn's multiple comparisons test (Zar, 2010).

\section{RESULTS}

Histochemistry. Four fiber types could be identified in the $N$. granulata claw closer muscle. The m-ATPase technique allowed the differentiation of slow (I) and fast (IV) contracting fibers, in addition to two intermediate types (II, III) (Fig. 1a). C. angulatus, however, evidenced fiber types I, II and III (Fig. 2a). The SDH activity proved to be subsarcolemmal for all fiber types (Figs. $1 \mathrm{~b}$ and $2 \mathrm{~b}$ ). Type I fibers reacted weakly to the SDH, Sudan black and PAS techniques; they rendered negative reactions for acid and alkali preincubation treatments. Type IV fibers exhibited a strong/ very strong reaction for all techniques (Table II).

Table II. Histochemical fiber type composition of the claw closer muscle of Neohelice granulata and Cyrtograpsus angulatus acclimated at $10 \mathrm{psu}$.

\begin{tabular}{|c|c|c|c|c|c|c|}
\hline \multirow[t]{3}{*}{ Techniques } & \multicolumn{6}{|c|}{ Fiber types } \\
\hline & \multirow[t]{2}{*}{ I } & \multicolumn{2}{|c|}{ II } & \multicolumn{2}{|c|}{ III } & \multirow[t]{2}{*}{ IV } \\
\hline & & $\mathrm{L}$ & $\mathrm{S}$ & $\mathrm{L}$ & $\mathrm{S}$ & \\
\hline m-ATPase no preincubation & +1 & +2 & +2 & +3 & +3 & +4 \\
\hline m-ATPase pre-incubation at $\mathrm{pH} 10.05$ & - & - & - & - & +2 & +4 \\
\hline m-A TPase pre-incubation at $\mathrm{pH} 4.6$ & - & - & - & - & +2 & +4 \\
\hline $\mathrm{SDH}$ & +1 & +2 & +3 & +2 & +3 & +3 \\
\hline PAS & +1 & $+1 /+2$ & $+2 /+3$ & +2 & +3 & +3 \\
\hline Sudan Black B & +1 & +1 & +2 & +1 & +2 & +2 \\
\hline
\end{tabular}

Reactivities: (-), negative; (+1), weak; (+2), moderate; (+3), strong; (+4), very strong. L: large subtype; m-ATPase, myosin-adenosine triphosphatase; PAS, periodic acid Schiff; S: small subtype; SDH, succinic dehydrogenase. 

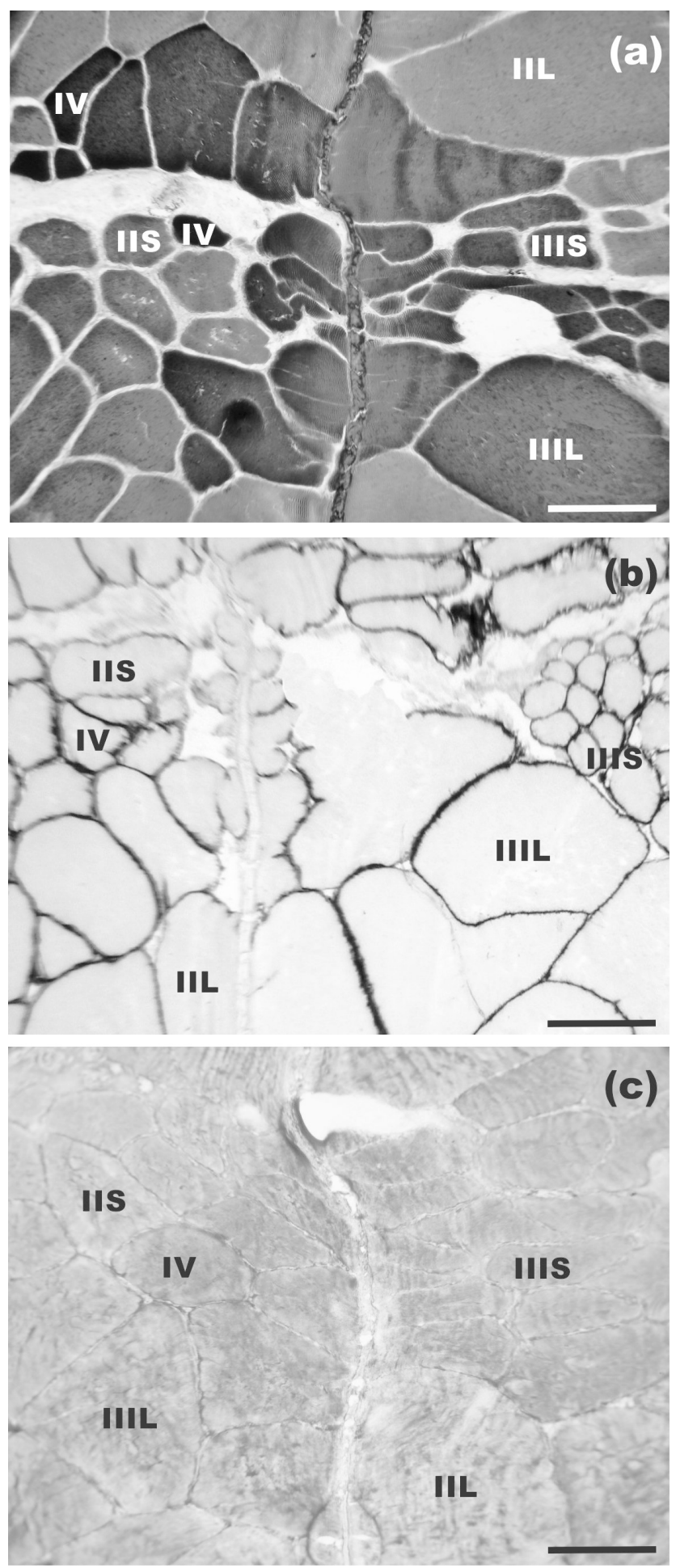

Fig. 1. Fiber type histochemistry of claw closer muscles of Neohelice granulata acclimated at salinity 10 psu. (a) Myosin-adenosine triphosphatase (m-ATPase) activity with no preincubation showing types II, III and IV. (b) All fiber types exhibited subsarcolemmal succinic dehydrogenase (SDH) activity. (c) Small (S) fibers react strongly to Periodic Acid Schiff (PAS), and large (L) fibers react moderately to this technique. Scale bars $=200 \mu \mathrm{m}$.
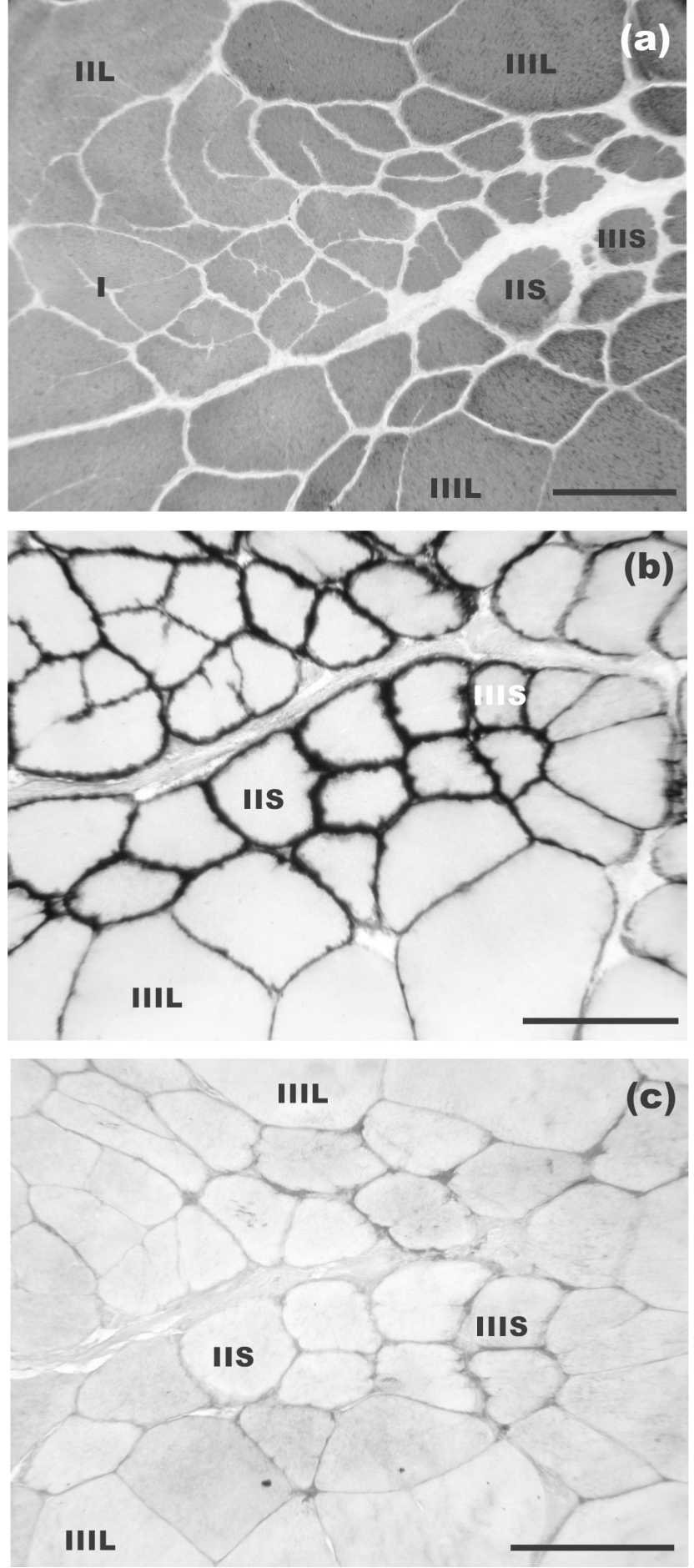

Fig. 2. Fiber type histochemistry of claw closer muscles of Cyrtograpsus angulatus acclimated at salinity 10 psu. (a) Myosinadenosine triphosphatase (m-ATPase) activity with no preincubation: three fiber types (I, II and III) are evident. (b) Succinic dehydrogenase (SDH) showing large (L) fibers with moderate stain intensity and small (S) fibers reacting strongly to this technique. (c) Type III exhibited a more intense reaction to Periodic Acid Schiff (PAS) than type II. Scale bars $=300 \mu \mathrm{m}$. 
Among the intermediate types two subtypes were identified on the basis of size and differential reaction to SDH, PAS and Sudan techniques: "Large" (L) and "Small" (S). To these techniques, the former showed a weak to moderate reaction and the latter a moderate to strong reaction (Figs. 1b, c and 2b, c). Additionally, subtypes IIIL and IIIS reacted differentially to acid and alkali preincubation treatments of the m-ATPase technique: fibers IIIL reacted negatively and fibers IIIS, in a moderate manner (Table II).

Table II shows a summary of the histochemical profile of $N$. granulata and $C$. angulatus claw closer muscles, acclimated at a salinity of $10 \mathrm{psu}$.

Morphometry. The Kruskall-Wallis test revealed a statistically significant effect of fiber types over diameters $(\mathrm{H}=119.308$; df
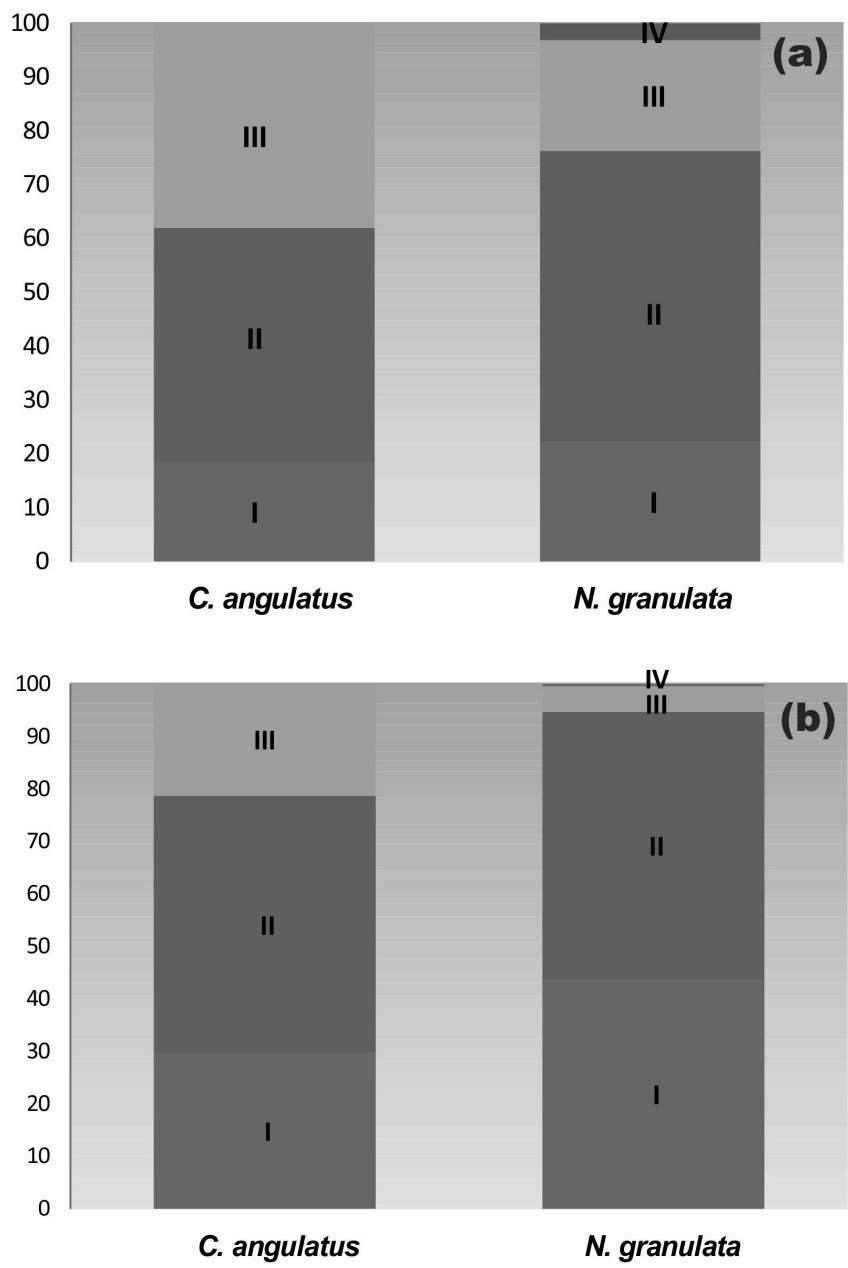

Fig. 3. Claw closer muscle morphometry of Neohelice granulata and Cyrtograpsus angulatus acclimated at salinity 10 psu. (a) Proportion of fiber types. (b) Relative Area of fiber types. Values on the y-axis are expressed as percentages.
$=6 ; \mathrm{P}=<0.001)$. Type I average diameter of $N$. granulata was significantly greater than types II $(\mathrm{Q}=$ 3.147; $\mathrm{P}<0.05)$, III $(\mathrm{Q}=6.092 ; \mathrm{P}<0.05)$ and IV $(\mathrm{Q}=$ 3.803 ; $\mathrm{P}<0.05)$. No significant differences were found between types II and III diameters $(\mathrm{Q}=4.142$; $\mathrm{P}<0.05)$, II and IV $(\mathrm{Q}=2.58 ; \mathrm{P}<0.05)$, and III and IV $(\mathrm{Q}=$ $0.695 ; \mathrm{P}<0.05)$. Types I and II average diameters of $C$. angulatus did not differ significantly $(\mathrm{Q}=2.111 ; \mathrm{P}<$ $0.05)$. Types I and II average diameters were significantly greater than type III $(\mathrm{Q}=5.156$ and $\mathrm{Q}=$ 3.951, respectively; $\mathrm{P}<0.05$ ). Comparing the average diameters for every fiber type separately, there are in general no significant differences between species $(\mathrm{P}<$ 0.05) (Table III).

The proportions of fiber types significantly differed between the two species $(\mathrm{c} 2=18.081 ; \mathrm{df}=3 ; \mathrm{P}$ $=<0.001)$. The intermediate types prevailed in $C$. angulatus (II and III), representing $81.57 \%$ of the total fiber population. In $N$. granulata a predominance of type II fibers followed by types I and III was observed. Type IV was scarce in $N$. granulata and it was absent in $C$. angulatus (Fig. 3a).

In $N$. granulata the relative area occupied by type I was greater than its relative proportion; $C$. angulatus followed the same pattern for types I and II. The rest of the fiber types exhibited the opposite pattern (II, III and IV in N. granulata and III in C. angulatus) (Fig. 3b).

Table III. Diameter of fiber types in the claw closer muscles of Neohelice granulata and Cyrtograpsus angulatus acclimated at $10 \mathrm{psu}$.

\begin{tabular}{lcc}
\hline Fiber type & \multicolumn{2}{c}{ Diameter $(\mu \mathrm{m} \pm \mathrm{SD})$} \\
& C. angulatus & $N$. granulata \\
\hline I & ${ }^{\mathrm{a}} 458.99 \pm 109.12$ & ${ }^{\mathrm{a}} 455.76 \pm 199.02$ \\
II & ${ }^{\mathrm{a}} 385.07 \pm 137.43$ & ${ }^{\mathrm{bc}} 314.67 \pm 169.44$ \\
III & b $271.89 \pm 153.92$ & ${ }^{\mathrm{bc}} 159.14 \pm 100.18$ \\
IV & & ${ }^{\mathrm{c}} 107.81 \pm 28.43$ \\
\hline
\end{tabular}

Similar superscripts express no statistically significant differences $(\mathrm{P}<0.05)$. Different superscripts indicate statistically significant differences $(\mathrm{P}<0.05)$.

\section{DISCUSSION}

The fiber heterogeneity in the crustacean limb muscles is the base to the functional heterogeneity of such limbs. This fact is evident in the pereiopod muscles of the diverse crustacean species (Neil et al.; Gruhn \& Rathmayer; Longo et al.; Longo \& Díaz 
2013a,b). In this study the claw closer muscle fibers of $N$. granulata and C. angulatus were classified into different groups according to their histochemical profile: I, of moderate contraction and low glycolytic and oxidative capacity; IV, rapid fibers, oxidative and glycolytic; II and III, of moderate contraction with a wide spectrum of glycolytic and oxidative properties. This is in accordance with Longo \& Díaz (2013a) for $N$. granulata and $C$. angulatus acclimated to osmoconforming conditions (35 psu $=$ control condition): fiber type IV would be involved in the continuous claw opening and closing movements of $N$. granulata during excavation; the slower and less resistant to fatigue fibers (types II and III) would be used by both crab species during exhibition, agonistic encounters and courtship.

The crustacean musculature shows a high degree of plasticity. It can occur at any time in the life of the individual, and is strongly linked to changes in the innervation pattern (Gruhn \& Rathmayer). Extrinsic factors, such as temperature, are also responsible of modifications of the muscle fibers phenotype. For example, variations in the expression of isoforms of temperature-dependent myofibrillar proteins of fish and crustaceans have been reported (Hirayama et al., 2000; Hooper \& Thuma, 2005). In gammarid amphipods it has been demonstrated that temperature variations associated to the high intertidal might be more selective for diversity of isoforms of heavy chain myosin than variations associated to different latitudes (Rock et al., 2009). In the fish Dicentrarchus labrax L. small variations in the developing embryo temperature increased growth and body length at larval and post-larval stages; it also accelerated the white muscle maturation, as evidenced by an increase in the fiber average diameter and the histochemical pattern of both the m-ATPase and the nicotinamide adenine dinucleotide tetrazolium reductase (NADH-TR) (López-Albors et al., 2003).

Crustaceans inhabiting tidal zones, coastal waters and estuaries are exposed to environmental changes, being salinity one of the key factors. These organisms show adjustment mechanisms at different levels -biochemical, physiological, morphological and/or behavioral- which allow them to withstand a wide range of environmental salinity (Kirschner; McNamara \& Faria; Romano \& Zeng). Mechanisms seem to depend on the species, habitat and stress type, and they do not always take place together (Freire et al.). Thus, N. granulata and C. angulatus exhibit differential responses at the biochemical level in gills, claw muscles and hepatopancreas at different environmental salinities, suggesting the existence of different adjustment mechanisms as regards to the osmo-ionoregulatory state of the crabs (Michiels et al.; Pinoni et al.).
The proportion of fiber types of $N$. granulata was variable with respect to a previous study, where this species was acclimated to salinity of 35 psu (osmoconformation = control condition); however, there were not differences in the proportion of fiber types regarding to control condition in C. angulatus (Longo \& Díaz, 2013a). This fact could be due to a differential phenotypic plasticity between species faced with changes of environmental salinity. On the other hand, the diameters of the different fiber types of both species were less than those observed at a salinity of 35 psu (Longo \& Díaz, 2013a). This would be caused by a smaller cell volume with reduced salinity because of both water and solute efflux (Freire et al.). In turn, the greater cell relation surface/volume at a lower salinity would allow an effective water and solutes interchange with the extracellular medium, decreasing the limitations associated to the large fiber size of these crustacean species (Hardy et al., 2009).

Hyper regulation is a physiological process with high energetic cost. It requires of such a metabolic reorganization that permits to face the energy demands associated to the activation of the osmo-ionoregulatory machinery (Freire et al.). Several studies have been carried out with $N$. granulata on the modifications suffered by the carbohydrates, lipids and proteins metabolism at different salinity conditions (Bianchini et al., 2008; Pinoni et al.). In the summer either the hypo or hyper osmotic shock induces gluconeogenesis in gills, muscles and hepatopancreas (Nery \& Santos; Schein et al., 2005; Martins et al.), which would correspond to the high glycogen content in the claw closer muscles of the $N$. granulata specimens used in this study. Thus, the glucose produced by gluconeogenesis would be stored as glycogen, to be later used as an energetic source during hyper regulation. On the contrary, no variations were observed in the glycogen content of $C$. angulatus when compared the results of the present study with those observed in acclimated specimens at a salinity of 35 psu (Longo \& Díaz, 2013a). On the other hand, the effect of the acclimation salinity on the hepatopancreas histology and histochemistry of $C$. angulatus and $N$. granulata was studied, having been observed a similar response in both crab species (Longo \& Díaz, 2015).

From the study of seasonal variations in the energetic metabolism of the crab Ocypode quadrata coming from Praia do Siriú (Brazil), Vinagre et al. (2007) suggested that lipids would be an important energy source during reproduction. Luvizotto-Santos et al. by using biochemical methods observed a mobilization of lipids in the gills and muscles of juveniles and adults of $N$. granulata acclimated at low salinities. At the same time, Michiels et al. demonstrated a significant increase in the lipase activity 
of the $C$. angulatus hepatopancreas at hyper regulation. On the other hand, Martins et al. found no significant variations of lipogenic activity in the $N$. granulata mandible muscle following a hypo osmotic stress. In this work, the lipid concentration of the claw closer muscle was both in $N$. granulata and C. angulatus similar to the one reported for osmoconformation conditions (Longo \& Díaz, 2013a).

In conclusion, $N$. granulata and $C$. angulatus exhibit differential responses at a histochemical level in the claw closer muscle at reduced salinity conditions. This fact is evidenced in the differential phenotypic plasticity of the muscle fiber type composition and in the different use of glycogen reserves in the muscle. On the other hand, claw closer muscle lipids of both species would not be required as an energy source during hyper regulation.

Therefore, the existence of different adjustment mechanisms in order to cope the salinity stress in the claw closer muscle of both euryhaline species is here suggested.

\section{ACKNOWLEDGMENTS}

This research is part of Longo MV Ph.D. thesis. It was supported by grants from the University of Mar del Plata, Argentina.

LONGO, M. V. \& DÍAZ, A. O. Influencia de la salinidad reducida sobre la composición histoquímica de tipos de fibras del músculo de cierre de las quelas de dos especies de cangrejos estuariales, Cyrtograpsus angulatus y Neohelice granulata (Decapoda: Varunidae). Int. J. Morphol., 35(2):533-540, 2017.

RESUMEN: Los crustáceos estuariales están expuestos a cambios frecuentes y abruptos en la salinidad ambiental que requieren ajustes a diferentes niveles en el tejido muscular. Se analizó la composición histoquímica de tipos de fibras del músculo de cierre de las quelas de Cyrtograpsus angulatus y Neohelice granulata (Dana, 1851) en condiciones de hiperregulación. Secciones de crióstato fueron tratadas con miosín-adenosín trifosfatasa (m-ATPasa), succinato deshidrogenasa (SDH), ácido periódico Schiff (PAS) y Sudan Black B. Se calcularon el diámetro promedio, el área y la proporción relativa de cada tipo de fibra. Los tipos I y IV serían grupos "extremos", mientras que los tipos II y III "intermedios". Las fibras del tipo I, de gran tamaño, exhibieron una reacción débil con todas las técnicas; las fibras del tipo IV, pequeñas, reaccionaron intensamente frente a los tests histoquímicos. Los tipos II y III predominaron en $C$. angulatus, mientras que el tipo II fue el más abundante en $N$. granulata. Las fibras del tipo IV fueron escasas en $N$. granulata y no se observaron en $C$. angulatus. El músculo de cierre de las quelas de $N$. granulata y $C$. angulatus exhibió respuestas diferenciales a nivel histoquímico en condiciones de salinidad reducida. De este modo, se sugiere la existencia de diferentes mecanismos de ajuste frente al estrés salino.

PALABRAS CLAVE: Cangrejos eurihalinos; Histoquímica; Hiperregulación; Fibras musculares; Estrés salino.

\section{REFERENCES}

Alberti, J.; Escapa, M.; Iribarne, O.; Silliman, B. \& Bertness, M. Crab herbivory regulates plant facilitative and competitive processes in Argentinean marshes. Ecology, 89(1):155-64, 2008.

Bianchini, A.; Lauer, M. M.; Nery, L. E.; Colares, E. P.; Monserrat, J. M. \& Dos Santos Filho, E. A. Biochemical and physiological adaptations in the estuarine crab Neohelice granulata during salinity acclimation. Comp. Biochem. Physiol. A Mol. Integr. Physiol., 151(3):423-36, 2008.

Freire, C. A.; Onken, H. \& McNamara, J. C. A structure-function analysis of ion transport in crustacean gills and excretory organs. Comp. Biochem. Physiol. A Mol. Integr. Physiol., 151(3):272-304, 2008.

Gruhn, M. \& Rathmayer, W. Phenotype plasticity in postural muscles of the crayfish Orconectes limosus Raf.: correlation of myofibrillar ATPasebased fiber typing with electrophysiological fiber properties and the effect of chronic nerve stimulation. J. Exp. Zool., 293(2):127-40, 2002.

Günzel, D.; Galler, S. \& Rathmayer, W. Fibre heterogeneity in the closer and opener muscles of crayfish walking legs. J. Exp. Biol., 175:267-82, 1993.

Hardy, K. M.; Dillaman, R. M.; Locke, B. R. \& Kinsey, S. T. A skeletal muscle model of extreme hypertrophic growth reveals the influence of diffusion on cellular design. Am. J. Physiol. Regul. Integr. Comp. Physiol., 296(6):R1855-67, 2009.
Hirayama, Y.; Sutoh, K. \& Watabe, S. Structure-function relationships of the two surface loops of myosin heavy chain isoforms from thermally acclimated carp. Biochem. Biophys. Res. Commun., 269(1):237-41, 2000.

Hooper, S. L. \& Thuma, J. B. Invertebrate muscles: muscle specific genes and proteins. Physiol. Rev., 85(3):1001-60, 2005.

Johnson, P. T. Histology of the Blue Crab, Callinectes Sapidus. A Model for the Decapoda. New York, Praeger Publishers, 1980.

Kirschner, L. B. The mechanism of sodium chloride uptake in hyperregulating aquatic animals. J. Exp. Biol., 207(Pt. 9):1439-52, 2004.

Li, E.; Chen, L.; Zeng, C.; Yu, N.; Xiong, Z.; Chen, X. \& Qin, J. G. Comparison of digestive and antioxidant enzymes activities, haemolymph oxyhemocyanin contents and hepatopancreas histology of white shrimp, Litopenaeus vannamei, at various salinities. Aquaculture, 274(1):80-6, 2008

Longo, M. V.; Goldemberg, A. L. \& Díaz, A. O. The claw closer muscle of Neohelice granulata (Grapsoidea, Varunidae): a morphological and histochemical study. Acta Zool., 92(2):126-33, 2011.

Longo, M. V. \& Díaz, A. O. The claw closer muscle of two estuarine crab species, Cyrtograpsus angulatus and Neohelice granulata (Grapsoidea, Varunidae): histochemical fibre type composition. Acta Zool., 94(2):2339, 2013a. 
Longo, M. V. \& Díaz, A. O. Morphology of the claw closer muscle in two estuarine crab species (Crustacea, Varunidae): an ultrastructural study. Zoolog. Sci., 30(8):663-9, 2013b.

Longo, M. V. \& Díaz, A. O. Histological and histochemical study of the hepatopancreas of two estuarine crab species, Cyrtograpsus angulatus and Neohelice granulata (Grapsoidea, Varunidae): Influence of environmental salinity. Zool. Sci., 32(2):163-70, 2015.

López-Albors, O.; Ayala, M. D.; Gil, F.; García-Alcázar, A.; Abellán, E.; Latorre, R.; Ramírez-Zarzosa, G. \& Vázquez, J. M. Early temperature effects on muscle growth dynamics and histochemical profile of muscle fibres of sea bass Dicentrarchus labrax L., during larval and juvenile stages. Aquaculture, 220(1-4):385-406, 2003.

Luvizotto-Santos, R.; Lee, J. T.; Branco, Z. P.; Bianchini, A. \& Nery, L. E. Lipids as energy source during salinity acclimation in the euryhaline crab Chasmagnathus granulata dana, 1851 (crustacea-grapsidae). J. Exp. Zool. A Comp. Exp. Biol., 295(2):200-5, 2003.

Maier, L.; Rathmayer, W. \& Pette, D. pH lability of myosin ATPase activity permits discrimination of different muscle fibre types in crustaceans. Histochemistry, 81(1):75-7, 1984

Martins, T. L.; Chittó, A. L.; Rossetti, C. L.; Brondani, C. K.; Kucharski, L. C. \& Da Silva, R. S. Effects of hypo- or hyperosmotic stress on lipid synthesis and gluconeogenic activity in tissues of the crab Neohelice granulata. Comp. Biochem. Physiol. A Mol. Integr. Physiol., 158(4):400$5,2011$.

McManus, J. F. Histological and histochemical uses of periodic acid. Stain Technol., 23(3):99-108, 1948.

McNamara, J. C. \& Faria, S. C. Evolution of osmoregulatory patterns and gill ion transport mechanisms in the decapod Crustacea: a review. $J$. Comp. Physiol. B, 182(8):997-1014, 2012.

Michiels, M. S.; del Valle, J. C. \& López Mananes, A. A. Effect of environmental salinity and dopamine injections on key digestive enzymes in hepatopancreas of the euryhaline crab Cyrtograpsus angulatus (Decapoda: Brachyura: Varunidae. Sci. Mar., 77(1):129-36, 2013.

Moriyasu, M. \& Mallet, P. Molt Stages of the Snow Crab Chionoecetes opilio by Observation of Morphogenesis of Setae on the Maxilla. $J$. Crustacean Biol., 6(4):709-18, 1986.

Neil, D. M.; Fowler, W. S. \& Tobasnick, G. Myofibrillar protein composition correlates with histochemistry in fibres of the abdominal flexor muscles of the Norway lobster Nephrops norvegicus. J. Exp. Biol., 183:185202, 1993

Nery, L. E. M. \& Santos, E. A. Carbohydrate metabolism during osmoregulation in Chasmagnathus granulata Dana, 1851 (CrustaceaDecapoda). Comp. Biochem. Physiol. B, 106:747-53, 1993.

Olivier, S. R.; Escofet, A.; Penchaszadeh, P. E. \& Oresanz, J. M. Estudios ecológicos en la región estuarial de Mar Chiquita (Buenos Aires, Argentina). II. Relaciones tróficas interespecíficas. An. Com. Investig. Cient., 1972:89-104, 1972.

Perry, M. J.; Tait, J.; Hu, J.; White, S. C. \& Medler, S. Skeletal muscle fiber types in the ghost crab, Ocypode quadrata: implications for running performance. J. Exp. Biol., 212(Pt. 5):673-83, 2009.

Pinoni, S. A. \& López Mañanes, A. A. Partial characterization and response under hyperregulating conditions of $\mathrm{Na}+\mathrm{K}+\mathrm{ATPase}$ and levamisolesensitive alkaline phosphatase activities in chela muscle of the euryhaline crab Cyrtograpsus angulatus. Sci. Mar., 72(1):15-24, 2008.

Pinoni, S. A. \& López Mañanes, A. A. Na+ATPase activities in chela muscle of the euryhaline crab Neohelice granulata: Differential response to environmental salinity. J. Exp. Mar. Biol. Ecol., 372(1-2):91-7, 2009.

Pinoni, S. A.; Michiels, M. S. \& López Mañanes, A. A. Phenotypic flexibility in response to environmental salinity in the euryhaline crab Neohelice granulata from the mudflat and the saltmarsh of a SW coastal lagoon. Mar. Biol., 160:2647-61, 2013.

Rock, J.; Magnay, J. L.; Beech, S.; El Haj, A. J.; Goldspink, G.; Lunt, D. H. \& Whiteley, N. M. Linking functional molecular variation with environmental gradients: myosin gene diversity in a crustacean broadly distributed across variable thermal environments. Gene, 437(1-2):60-
70, 2009.

Romano, N. \& Zeng, C. Osmoregulation in decapod crustaceans: implications to aquaculture productivity, methods for potential improvement and interactions with elevated ammonia exposure. Aquaculture, 334-337:12-23, 2012.

Schein, V.; Chittó, A. L. F.; Etges, R.; Kucharski, L. C.; van Wormhoudt, A. \& Da Silva, R. S. M. Effects of hypo-or hyperosmotic stress on gluconeogenesis, phosphoenolpyruvate carboxykinase activity, and gene expression in jaw muscle of the crab Chasmagnathus granulata: seasonal differences. J. Exp. Mar. Biol. Ecol., 316(2):203-12, 2005.

Spivak, E. D. Cangrejos estuariales del Atlántico sudoccidental $\left(25^{\circ}-41^{\circ} \mathrm{S}\right)$ (Crustacea: Decapoda: Brachyura). Invest. Mar, 25:105-20, 1997.

Vinagre, A. S.; Nunes do Amaral, A. P.; Ribarcki, F. P.; Fraga da Silveira, E. \& Périco, E. Seasonal variation of energy metabolism in ghost crab Ocypode quadrata at Siriú Beach (Brazil). Comp. Biochem. Physiol. A Mol. Integr. Physiol., 146(4):514-19, 2007.

Zar, J. H. Biostatistical Analysis. $5^{\text {th }}$ ed. New Jersey, Pearson Prentice Hall, 2010.

\author{
Corresponding author: \\ Dra María Victoria Longo \\ M. V. Longo. Instituto de Investigaciones \\ Marinas y Costeras (IIMyC) \\ Universidad Nacional de Mar del Plata \\ CONICET. Funes $32503^{\circ}$ piso, 7600 \\ Mar del Plata \\ Buenos Aires \\ ARGENTINA
}

E-mail: mvlongo@mdp.edu.ar

Received: 05-12-2016

Accepted: 08-03-2017 